\title{
THE IMPACT OF THE IPA CROSS-BORDER CO-OPERATION HUNGARY - CROATIA 2007 - 2013 PROGRAMME - INFRASTRUCTURE, TOURISM AND HUMAN CAPITAL
}

\author{
Sanela Ravlić \\ PhD, Senior Adviser for project implementation, Croatian Employment Service Regional Office, Kneza \\ Trpimira 2, 31000 Osijek, Croatia; e-mail: sanelaaaaa@gmail.com \\ Jerko Glavaš \\ PhD, Associate Professor, J. J. Strossmayer University of Osijek, Faculty of Economics in Osijek, \\ Trg Ljudevita Gaja 7, 31000 Osijek, Croatia; e-mail: jerko.glavas@efos.hr \\ Mislav Šimunić \\ PhD, Full Professor, University of Rijeka, Faculty of Tourism and Hospitality Management, Primorska 42, \\ 51410 Opatija, Croatia; e-mail: mislavs@fthm.hr
}

\begin{abstract}
The main purpose of the paper is to move towards quantification and clear distinction of invested IPA funds in the CBC area of Hungary and Croatia 2007. - 2013. Objective of the paper is to provide an insight into the real impact of allocated financial resources to the extent that was not examined so far at the level of institutions (lead beneficiary and project partners) and target group members. The main research questions is what is the impact that implemented projects in IPA CBC HU - CRO had in terms of different types of institutions, types of activities (educational or infrastructure), beneficiaries in local communities and regional development? The research was conducted in April/May 2018. The questionnaire consisted of 41 variables. Interview was the corrective method. Data analysis was conducted using SPSS v23. Total of 102 respondents participated, representing 358 institutions that implemented projects in the cross-border area. Data were first analysed using descriptive statistics, then compared by using t-test and ANOVA Chi-square test was performed to determine the likelihood of correlation between variables. Paper shows obtained results on personal, organisational and regional level. The outcome confirms the difference between human capital in institutions that implement projects and high dependence of EU funds in entire region. Beneficiaries are more aware of impact that lifelong learning activities can have on their labour market competitiveness. Investment in sustainable environment, tourism, development of economic cooperation, infrastructure and common human capacities will have a significant impact in the region.
\end{abstract}

Key words: human capital, European Union, regional development, cross-border cooperation 


\section{INTRODUCTION}

By implementing projects in the cross-border area, networking among stakeholders, transfer of knowledge, education, skills development and exchange of best case practices among partners, there is a chance to develop human and other resources. However, there is a noticeable absence of willingness to determine the results on all levels that the projects within this cross-border programme have achieved. It is necessary to determine which direct and indirect effects the invested funds were able to ultimately achieve in the seven years of programme implementation. In the six cross-border cooperation programmes, with the exception of transnational programmes in which the Republic of Croatia has participated, more than 150,000,000 euro has been allocated, but the question of the effect of the invested funds spent is raised. Except for indicators at the level of each individual project, no clear review of the impact of these funds has been made for the observed area in order to assess the real impact of the funds invested on both sides of the border. In the document Strategic Framework for Development of Republic of Croatia 2006-2013., it was defined that a special emphasis is put on cross-border cooperation as one of the instruments of regional development. The project implementation and its success is of the utmost importance for the EU, given that it secures the continued operation and achievement of the project objectives after the completion its formal financing. It is expected that the achieved results and positive changes will be further spread in the community in which the project was implemented, and that in the future these created values will become the basis for further development, both for individuals who participated in the implementation of the project at personal level and at the level of community in which the interventions took place (Ravlić, 2019). Moreover, possible distinction between funds invested in different components should be detected for the future plans and actions since substantial amounts are being granted for this area.

The observed IPA Cross-border Program Hungary-Croatia 2007-2013, with more than $52.000 .000 .00 €$ allocated funds for seven years of the program, which has been the focus of this study, funded projects in the area of sustainable environment and tourism, development of economic cooperation, infrastructure and common human capacities, which are recognized as areas of exceptional local-specific importance of the cross-border area. As stated in the „Ongoing Programme Evaluation of the Hungary - Croatia IPA Cross-border Cooperation Programme 2007-2013" it would be useful to "measure longer term effects of the funded activities and to ensure deeper knowledge capitalisation", which is an additional confirmation of the necessity for this research. Therefore, the aim is to investigate and present the perception of the investments' impacts created within the organisations that had a status of lead beneficiary or project partner primarily on the development of the human potential of the observed area and perception on the influence on regional development.

\section{LITERATURE REVIEW}

Human capital is important when we discuss its potential for multiplication effect in local communities that can be created due to the invested funds in the cross-border area of two countries. Investment in education and the acquisition of knowledge has been recognized as an important component of the European Union's development, which under the Lisbon Strategy has 
highlighted investing in people as one of the main prerequisites for creating a modern knowledgebased economy (Babić, 2005:30). In recent years, the Republic of Croatia invested considerable funds in the development of its institutional framework for an efficient regional development, as well as in human resources development (Marijanović et al., 2010:991), but its effect and actual impact has not been thoroughly researched. Knowledge has become the key to economic competitiveness and success. An important part of an economy's overall competitiveness - the ability to achieve success on markets - is labour-force competitiveness (Bejaković, 2006:109) that has to be understood and accepted on all levels and by all who participate and/or influence the labour market. When discussing about the observed area, on the Croatian side it is inevitable to take into consideration past events that shaped the future of the area. The economies of the countries in the region are burdened by two severe legacies: the arrangements of the old socialist semi-planned economy and the damaged structures of the war economies of the $1990 \mathrm{~s}$ (Altman, 2004:69). Even since the declaration of independence, and especially after the end of the war (1995), Croatia faced a series of problems in the regional development field, such as: socioeconomic disparities between different regions, depopulated areas (caused by the homeland war), large number of refugees, neglected technological and transport infrastructure (UNDP, 1999). The regional disparities that influence huge development gaps were inherited from the previous system (Dragičević, Letunić, 2008:3). Also, the combination of an unfavourable external environment and subdued domestic demand has taken a toll on the Croatian economy. Croatia is one of the few countries where real GDP has not grown at all since the beginning of the global financial crisis. This has worsened the fiscal picture, with public debt approaching 60\% of GDP(Koerner et al., 2013:1). It should be highlighted that utilization of IPA funds overlapped with the years that crisis hit the entire EU market.

Most of the research conducted in the world indicate a positive link between investment in human capital and economic growth rates, yet it is often not possible to fully and accurately establish a clear correlation between the observed variables, which will show constancy in value when tested and observed. The reason is often in a large number of variables that affect the level of human potential, but also in the reasons for its loss over time, or over a longer period of time. Macroeconomists have indeed offered a number of models and theories in order to explain how investing in education is affecting economic growth. Research that, given the different position of education and the coverage of matter, show a significant and positive relationship between human capital and economic growth, are found in the works of the author Barro (1990), Otani and Villanueva (1990), Mankiw et al (1992), Judson (1996), Hansen and Knowles (1998), Poorfaraj et al (2011) and others. Additionally, approximately a third of the EU's total budget is invested in regional policy in order to achieve greater economic and social cohesion of the Union more equitable development of member states and their regional units (Tišma et al., 2012:120).

Effects caused by the project implementation can be observed, except in organisations that implemented projects, also through the effects that it can achieve on the level of target group members, including members of the immediate and their extended family. Every town, city and community has unique local conditions that either help or hinder its economic development. These conditions will form the basis for designing and implementing a local economic development 
strategy (Swinburn, 2006:3). As highlighted in the Strategic Development Framework 2006 - 2013 „The reward for accepting the ambitious view that anything can be changed in the long run may be surprisingly copious. Such an approach indicates that we should act in the areas that today seem difficult to change. A small step from today to tomorrow may lead to a great stride from tomorrow to the day after. The main source and driver of this change are people - people prepared to learn and accept the challenges". People, are becoming a strategic basis for the development of modern competitive economies and societies with their specific and unique combination of ideas, information, new knowledge and skills. The objective of regional development policy is to contribute to the socio-economic development of the Republic of Croatia, in accordance with the principles of sustainable development, by creating conditions that will enable all parts of the country to strengthen competitiveness and realize their own development potentials (Bilas et al., 2011:296). Increasingly, competitiveness and prosperity depend on the capacity of the people and businesses located there to make the best use of all of territorial assets. In a globalising and interrelated world economy, however, competitiveness also depends on building links with other territories to ensure that common assets are used in a coordinated and sustainable way. Cooperation along with the flow of technology and ideas as well as goods, services and capital is becoming an ever more vital aspect of territorial development(...)of the EU as a whole (CEC, 2008).

\section{METHOD}

\section{1 Design}

The research, which will partially be presented in this paper, was conducted from 1st of April to 31st of May 2018. The survey consisted of 38 questions (41 variables). The corrective method was the interview method. The collected data were processed by appropriate statistical methods. Data analysis was done using SPSS V23. The focus is definitely on the insufficient monitoring of the effectiveness that invested funds created in the development of resources in the observed crossborder region of Hungary and the Republic of Croatia at the personal, institutional and local level.

\section{2 Research group}

The respondents were project managers from organisation that implemented projects during the 7-year period from 2007 to 2013, according to the $n+3$ rule. Of the potential 170, 102 respondents participated, representing 358 institutions out of a total of 581 institutions that took part in the projects under the 3 conducted Calls. The involved institutions included public sector institutions, educational and research institutions, trust funds, various chambers, public employment services, regional and local authorities (counties, cities and municipalities), regional development agencies, business incubators, entrepreneurial centres, R\&D centres, associations, NGOs, employers' associations, professional associations, trade unions, agricultural associations and cooperatives. 


\subsection{Instruments}

The data was collected by using the Type Form online form. The form was, beside on Croatian language also offered in Hungarian language for organisations from Hungary in order to encourage them to fill in the questionnaire. Out of entire scope of conducted research several answers to the questions will be presented, as an example, to show the created impact of funds that were invested in different areas but also to distinguish the organisations capacities, their realities during project implementation and other factors that influenced their resources.

\section{RESULTS}

First section shows the types of organizations that took part in the questionnaire and the grouping of data that will be used in the further statistical processing. Table 2. show total number of project team members for each group of the respondents according to the new grouping of organizations. Next is a table that presents the calculation of the possible difference between the groups, thus the $\mathrm{HR}$ that is working in those institutions. Table 4. presents the data collected for the question about pre-financing of the project activities that was mandatory under IPA programme CBC Hungary - Croatia. Within the next table chi-square test was performed to determine the likelihood of correlation between selected variables. Table 6. show the results of three statements regarding the attitude of project implementers under the IPA CBC HU -HR 2007 - 2013 programme. Last two selected tables show the results of opinion of respondents regarding the impact on regional development that was created by investment in infrastructural or educational component of the project they implemented in the region.

Table 1. Type of organization

\begin{tabular}{|c|c|c|c|c|}
\hline & Frequency & Percent & $\begin{array}{c}\text { Valid } \\
\text { Percent }\end{array}$ & $\begin{array}{c}\text { Cumulative. } \\
\text { Percent }\end{array}$ \\
\hline Institution & 42 & 41,2 & 41,2 & 41,2 \\
Regional and local government & 24 & 23,5 & 23,5 & 64,7 \\
Regional development agency & 22 & 21,6 & 21,6 & 86,3 \\
Non-governmental organization (NGO) & 9 & 8,8 & 8,8 & 95,1 \\
State/Local government owned company & 5 & 4,9 & 4,9 & 100,0 \\
Total & 102 & 100,0 & 100,0 & \\
\hline
\end{tabular}

Source: Authors

During the formation of the questionnaire, the question about the organizational structure has several possible answers, as follows: (a) Institution: public sector institutions, educational and research institutions; (b) Regional and local authorities (counties, cities, municipalities); (c) Regional development agencies, local development agencies; (d) Business incubators, entrepreneurial centers, R\&D centers and other business support organizations; (e) Chambers of Commerce, Chambers of Commerce and Commerce, Public Employment Services; (f) Non-governmental organizations: civil organizations, professional associations, trade unions; (g.) Foundations; (h) 


\section{S. Ravlić, J. Glavaš, M. Šimunić: The Impact of the IPA Cross-Border Co-operation Hungary - Croatia... Zbornik Veleučilišta u Rijeci, Vol. 8 (2020), No. 1, pp. $135-149$}

Other. The small number of responses collected in individual categories could affect the ability to analyse and possibly present valid results when testing individual answers to questions, or their further interpretation so the new clustering of data was undertaken, which would not diminish the significance of certain collected data, but allow their accurate presentation, taking into account all similarities and significant differences, but respecting the original intention of the questions. Therefore, the tourist board and chamber were merged with institutions, while the foundation was merged with associations and a new group of non-governmental organizations was formed. In addition, a group of entrepreneurial support institutions has been created, into which development agencies of all levels, business incubators, entrepreneurial centers, R\&D centers have been merged. The grouping of data in the graphical representation was used in further statistical processing of the obtained data according to the representation in the table above.

Table 2. Total number of project team members

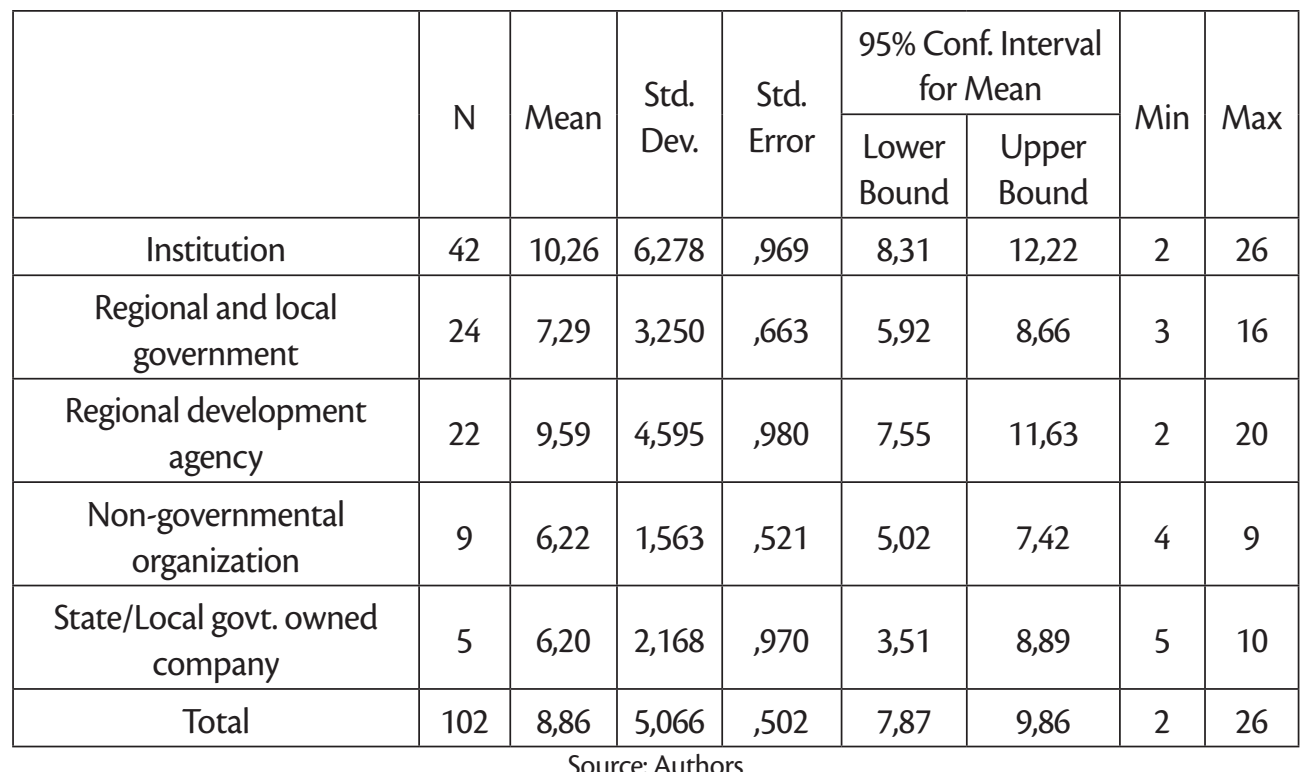

The data collected was subjected to an ANOVA test to test the significance of differences between groups, including all relevant statistical indicators, such as standard deviation and average, in a complex model. Since the variance analysis test determines the existence or non-existence of differences between more than two groups taking into account arithmetic means, usually under the null hypothesis it is stated that differences between groups are not statistically significant. In this case, we assume that the groups are quite similar in this respect in their responses to a particle measuring quantity, intensity, etc. 
Table 3. Total number of project team members (ANOVA)

\begin{tabular}{|c|c|c|c|c|c|}
\hline & Sum of Squares & $\mathrm{df}$ & $\begin{array}{c}\text { Mean } \\
\text { Square }\end{array}$ & $\mathrm{F}$ & Sig. \\
\hline $\begin{array}{c}\text { Between } \\
\text { Groups }\end{array}$ & 251,327 & 4 & 62,832 & 2,604 &, 041 \\
\hline Within Groups & 2340,751 & 97 & 24,131 & & \\
\hline Total & 2592,078 & 101 & & \\
\hline
\end{tabular}

The calculation confirmed that the difference between the groups is considerable (Sig. Value is 0.041), despite the extremely large variations within individual groups. This clearly confirms the possible difference between human capital among institutions who implement projects funded by the EU, in terms of their capabilities but also the costs of labour for certain institution.

Table 4. Own financing of the project (Cross tabulation)

\begin{tabular}{|c|c|c|c|c|c|c|c|}
\hline & \multicolumn{5}{|c|}{ Type of organization } & \multirow[b]{2}{*}{ Total } \\
\hline & & Institution & $\begin{array}{c}\text { Reg. } \\
\text { development } \\
\text { agencies }\end{array}$ & $\begin{array}{c}\text { Reg. } \\
\text { development } \\
\text { agencies }\end{array}$ & NGO & $\begin{array}{c}\text { State/ } \\
\text { Local } \\
\text { govt. } \\
\text { owned } \\
\text { company }\end{array}$ & \\
\hline \multirow{2}{*}{ No } & No. & 20 & 9 & 13 & 0 & 5 & 47 \\
\hline & $\%$ & $47,6 \%$ & $37,5 \%$ & $59,1 \%$ & $0,0 \%$ & $100,0 \%$ & $46,1 \%$ \\
\hline \multirow{2}{*}{ Yes } & No. & 21 & 12 & 6 & 7 & 0 & 46 \\
\hline & $\%$ & $50,0 \%$ & $50,0 \%$ & $27,3 \%$ & $77,8 \%$ & $0,0 \%$ & $45,1 \%$ \\
\hline \multirow{2}{*}{$\begin{array}{l}\text { I do not } \\
\text { know }\end{array}$} & No. & 1 & 3 & 3 & 2 & 0 & 9 \\
\hline & $\%$ & $2,4 \%$ & $12,5 \%$ & $13,6 \%$ & $22,2 \%$ & $0,0 \%$ & $8,8 \%$ \\
\hline \multirow{2}{*}{ Total } & No. & 42 & 24 & 22 & 9 & 5 & 102 \\
\hline & $100,0 \%$ & $100,0 \%$ & $100,0 \%$ & $100,0 \%$ & $100,0 \%$ & $100,0 \%$ & \\
\hline
\end{tabular}

Source: Authors

Table 4. shows the collected results for the question about the issues the organisation faced regarding the first reimbursement, i.e. if it has been a big challenge for the organization in order to prepare and implement all the project activities? For the purpose of a more detailed processing of the obtained results, a chi-square test was performed to determine the potential deviation of frequencies from the expected frequencies. We use it when trying to determine the likelihood of correlation between variables, and usually when the assumption is made that there is no difference in frequencies between some groups of subjects. 
Table 5. Chi-Square Tests

\begin{tabular}{|c|c|c|c|}
\hline & Value & $\mathrm{df}$ & Asymptotic Significance (2-sided) \\
\hline Pearson Chi-Square & $19,997^{\mathrm{a}}$ & 8 &, 010 \\
\hline Likelihood Ratio & 26,004 & 8 &, 001 \\
\hline No. of Valid Cases & 102 & & \\
\hline
\end{tabular}

The test negates it and confirms that there is an extremely large difference in the own financing of the implementation of the project by the institution until the first disbursement by budget users relative to the non-governmental sector.

The answer is negative, i.e. financing up to the first payment is not a problem in $100 \%$ of the responses of companies owned by regional or local government or the state, almost $60 \%$ of the responses of entrepreneurial support institutions and $47,6 \%$ of the responses of institutions. Regional and local self-government bodies show an almost percentage as it comes from responses from organizations that are located both in larger and smaller cities, towns and villages so it certainly depends on their financial strength.

Table 6. Attitude of project implementers under the IPA CBC HU-HR 2007 - 2013

\begin{tabular}{|c|c|c|c|c|c|c|}
\hline Statement & (1) & (2) & (3) & (4) & (5) & $\begin{array}{c}\text { Ar. } \\
\text { mean. }\end{array}$ \\
\hline $\begin{array}{c}\text { Our organization would certainly establish } \\
\text { partnerships with organizations from another } \\
\text { country, partners in the project and carry out the } \\
\text { activities of this project in this volume and without } \\
\text { EU funding or co-financing. }\end{array}$ & 50,0 & 23,5 & 15,7 & 7,8 & 2,9 & 1,90 \\
\hline $\begin{array}{c}\text { Partner organizations have greatly helped to } \\
\text { develop the skills, knowledge and capabilities of our } \\
\text { organization }\end{array}$ & 2,9 & 4,9 & 19,6 & 41,2 & 31,4 & 3,93 \\
\hline $\begin{array}{c}\text { By transferring knowledge, skills and experience, we } \\
\text { have made it possible to improve our own business } \\
\text { as well as that of our partners and associates in the } \\
\text { project. }\end{array}$ & 1,0 & 2,9 & 15,7 & 48,0 & 32,4 & 4,08 \\
\hline
\end{tabular}

Source: Authors

The statements in the table 6. range from $1-5$, where 1 stands for "I strongly disagree", number 2 "I disagree", 3 is "neither agree nor disagree", grade 4 is "I agree" and 5 is for "I completely agree with the statement".

The first statement clearly points to the fact that partner organizations on both sides of the border do not make contact and spend planned project to the extent that they did so by supporting EU 
funds through IPA CBC HU - HR 2007-2013. (50\% in the case of a "disagree" answer to which we can add and 23,5\% a "disagree" answer). Only $15,7 \%$ of respondents expressed uncertainty and chose the answer "neither agree nor disagree", and quite low number of respondents $(7,8 \%)$ "I agree", while 2,9\% of respondents "completely agree". Mean is at 1,90.

In the case of the second statement, of the total number of respondents, only 2,9\% "disagree" with the statement that partner organizations helped to develop the skills, knowledge and capabilities of their organization, as well as $4,9 \%$ who do not "sufficiently" agree with the claim, which can be considered a success given the very low percentage of such projects in relation to their total number. $19,6 \%$ of the respondents answered "neither agree nor disagree". The reason for this percentage may be the type of activities carried out by the organizations, that is, more emphasis is placed on the users themselves, and less on the linking of institutions and the transfer of knowledge and examples of good practice. Also, there was a language barrier on the part of the conductors, which could often not be heard during the seven-year implementation period. Although each conference or activity of this nature had a simultaneous translation, implementers still noted barriers to daily communication with their partners, which could be the cause of this response rate. More than two-thirds of the respondents answered yes to this statement, and $41,2 \%$ of respondents agree with it, while $31,4 \%$ of respondents completely agree with the stated statement. Mean is 3,93.

In the case of the last statement, where the mean is 4,08 , the respondents show a really high degree of agreement with the statement that the implementation of this project has increased the number of contacts and cooperation with organizations at the local level, because as many as $47,1 \%$ of the respondents opted for the answer "I agree" and answered agree" $41,2 \%$ of respondents. Only a low $4,9 \%$ of respondents disagreed with the statement, while $6,9 \%$ of respondents did not express their clear position on the statement.

Table 7. Impact on regional development

\begin{tabular}{|c|c|c|c|c|}
\hline Type of projects & N & Mean & Std. Deviation & Std. Error Mean \\
\hline Infrastructural component & 12 & 4,42 &, 515 &, 149 \\
\hline Educational component & 90 & 4,06 &, 740 &, 078 \\
\hline
\end{tabular}

When discussing projects implemented in the 7 year period, it is needed to take into consideration the difference of project components, thus their infrastructural of educational component which will be invested in sustainability of environment or tourism on both sides of the border together with their impact on regional development. Beside the impact, the possible difference that the invested funds in specific components could create, should be detected. 
Table 8. Difference of created impact on regional development

\begin{tabular}{|c|c|c|c|c|c|c|c|}
\hline & \multicolumn{3}{|c|}{$\begin{array}{c}\text { Levene's Test for } \\
\text { Equality of Variances }\end{array}$} & \multicolumn{5}{|c|}{ t-test for Equality of Means } \\
\cline { 2 - 8 } & $\mathrm{F}$ & Sig. & $\mathrm{t}$ & $\mathrm{df}$ & $\begin{array}{c}\text { Sig. } \\
\text { (2-tailed). }\end{array}$ & $\begin{array}{c}\text { Mean } \\
\text { Diff }\end{array}$ & Std. Error Diff. \\
\hline $\begin{array}{c}\text { Equal variances } \\
\text { assumed }\end{array}$ &, 070 &, 792 & 1,635 & 100 &, 105 &, 361 &, 221 \\
\hline $\begin{array}{c}\text { Equal variances } \\
\text { not assumed }\end{array}$ & & & 2,151 & 17,7 &, 046 &, 361 &, 168 \\
\hline
\end{tabular}

Source: Authors

\section{DISCUSSION}

Considering the existing divergence in development among the regions of the Republic of Croatia, one of the potential solutions is the usage of funds for cross-border cooperation programs. In addition to investing in infrastructure, those projects can include activities that stimulate the development of human capital through various forms of education, the development of tourism, entrepreneurial activities and the preservation of the environment on both sides of the border. In the Republic of Croatia EU funding has traditionally taken up a lot of media space, but there is insufficient mention of the effects and if it has resulted in an increase in the quality of life in a local community for all its stakeholders. One of the first to be mentioned are the organisations that are implementing activities in the cross-border area. In order to create impact in the $C B C$ area, there should be no difference among the organisations or issues they have to face in order to implement planned activities.

Regarding the table 2. and 3, the calculation confirmed that the difference between the groups is significant (Sig. value is 0,041 ), despite the extremely large variations within individual groups. Partnerships in which the project implementers are institutions, regional and local development agencies and regional and local authorities have more people working on the implementation of projects, which is probably largely conditioned by the nature of these institutions and its financial sources. They are financed from the local, regional or national authorities and do not depend on the implementation of the projects and the funds received from them, such as associations. The associations, as shown in the research, have on average fewer people working on project implementation. On the other hand, regional and local government or state-owned companies have almost the same number of people working on projects as associations, but 5 respondents (regional and local government or state-owned companies) have mostly implemented projects with an infrastructure component, which means a different division of project tasks where most of the tasks are delegated or subcontracted. It can be concluded that there is an impact on human capital, regardless the project size and the overall project result, since the implementation requires a high willingness to learn and development of transversal skills. Also, institutions, regional and 
local development agencies, regional and local government bodies can offer the acquisition of knowledge, skills and abilities to more people as more employees work on project implementation even though they have lesser work load than in the other institutions that are self-financed.

The data from the table 4. show the collected results for the question about the issues the organisation faced regarding the first reimbursement, i.e. if it has been a big challenge for the organization in order to prepare and implement all the project activities in the number and percentage. The data presented in the Table 5. organizations that are financed by the state/ regional or local government are not burdened at all with the pre-financing of the projects, while in the non-governmental sector it is almost always a problem, making a difference in the starting position - planning, preparation and application of projects. In this situation non-governmental sector, which is generally closer to the target group members in the local communities, is in the disadvantaged situation. This will certainly influence the preparation and application of projects to non-budget users as it requires more resources while planning and they will not be able to implement high-scale projects. Moreover, their human capital will not be able to develop their capabilities to their maximum since they will not be able to apply for higher amount of funds, thus more complex projects. On the other hand, people employed for the government might not be as challenged since their teams, as we have already seen, have more members and the work load is divided. Therefore, this situation has its own difficulties for each of the observed organizations and their human capital, both budget users and self-funded organizations.

All three statements from Table 6. show that partner organisations from both side, as part of the IPA CBC HU - CRO programs, have mutually influenced the development of skills, knowledge, capabilities of employees and business processes within the organization on both sides of the border. Also, the collected data confirm that most organisations would not surely establish partnerships with organizations from another country, partners in the project and carry out the activities of this project to this extent without EU funding or co-financing. If we talk in figures, that is if we put the analyzed data in the financial perspective of the Program, we will notice that it is a really considerable amount of funds that would not be invested and that would not have the opportunity to create changes in local communities along the Hungarian-Croatian border. If we add up the financial value of the implemented projects by $67,6 \%$ of the respondents who answered "I disagree" and "I disagree", we get a value of $29.098 .306,18$ euros, which is even $57,59 \%$ of the total budget of the whole of the seven-year Program. For the respondents who are not sure or "neither agree nor agree" with the statement, we cannot fully confirm whether they were implemented or not, $17,6 \%$ of them represent a total of $28,56 \%$ of the financial value of the Program. Expressed in Euros, it is $14.430 .888,06$ euro. According to the opinion of the respondents, projects that can be assumed to be implemented without the initial financial assistance of EU funds are represented with a low $13.85 \%$ or only $6.999 .544,02$ euro. According to the aforementioned, we can confirm the strong dependence of the implemented projects and the corresponding financial amounts to the EU funds, thus all the effects in the local communities they have influenced.

As shown in the table 8, the difference between impact on regional development based on the respondents who were the ones implementing activities in the cross-border region in the period of seven years was tested. Difference was tested taking into consideration infrastructural and 
educational component of the implemented projects. The result can be important on several levels but mostly it could be used for the planning of future actions in the cross-border region. To further examine the attitude of project implementers and if is there a difference between those who implemented projects with a greater infrastructure component compared to those with a educational component, a Student's t-test of independent samples was conducted. It found that, although visible, the differences were not statistically significant (Sig. $=0.105$ ). The importance of both types of project components for a local area, according to the implementers of such activities, is equal and the undertaken activities for both components would have a significant impact, both on the people and the area where the activities are being implemented.

\section{CONCLUSION}

Understanding the scarcity of resources of an area and the components of the real impact that those funds can create should be explored in more detail in order to find an approach that will produce the desired results.

The complexity of the reforms imposed by the EU accession process usually overburdens the national system, making the modernization and economic, politic, financial and administrative development very difficult both at national and regional level. In order for the process to succeed, it is necessary to have cooperation between the non-governmental actors and the private sector (...) since the reform as a process covers the entire civil society in its whole complexity, being more like a social process which takes place over generations. The experience of other states which have acceded to the EU shows that the successful implementation of a reform takes years (Ivan, Lov, 2010:111). Only synergy will allow these very delicate processes to occur and will be the basis for moving in the desired direction at the personal level, institutional level and finally for the entire local space.

Although there are many detectable impact factors in a certain area, it is still necessary to try to locate those that have the greatest impact. The analysis of the economic effects of EU integration is accompanied by a number of constraints that have to be taken into account when interpreting the results. First, it is not possible to explore (or, due to the high uncertainty, it is rather impossible to comprehend) all the economic costs and benefits of Croatia's accession to the EU. Additionally complicating the analysis is the fact that when evaluating the economic implications of the accession it is necessary to separate the processes of economic reforms, that would take place without the accession from the processes that are solely due to the integration itself (Lejour, Mervar and Verweij, 2008:2). Still, managing the resources of an area and using the available funds give us the real possibility to detect the bottleneck of a certain location, correct them and make more informed decisions in a certain situation in the future.

Further research in this area should certainly examine more "in depth" the real impacts that invested EU funds has created at the personal, local and regional level in the cross border areas of intervention. 


\section{REFERENCES}

Altmann, F. (2004) „Regional economic problems and prospects", Chaillot Paper: The Western Balkans Moving on, No. 70, Institute for Security Studies, European Union, Paris., Available at https://www.iss.europa.eu/sites/default/files/ EUISSFiles/cp070.pdf (10. 10. 2019.)

Babić, Z. (2005) „Participacija i ulaganje u obrazovanje u Hrvatskoj“. Privredna kretanja i ekonomska politika, Vol.14, No. 101, pp. 30.

Barro, R. J. (1990) “Government spending in a simple model of endogeneous growth". Journal of political economy, Vol. 98, No. 5, Part 2, pp. 103-125. http://dx.doi.org/10.1086/261726

Bejaković, P. (2006) “How prepared is Croatia for a knowledge-based society?”, Ott, K., Croatian Accession to the European Union: the Challenges of Participation, Zagreb: Institute for Public Finance, pp. 109-128.

Bilas, V., Franc, S., Cota, A. (2011) „Predpristupni fondovi Europske unije i Republika Hrvatska“. Ekonomska misao i praksa, Vol. , No. 1, pp. 289-309. Available at https://hrcak.srce.hr/69723 (9. 10. 2019.)

CEC (2008) „Green Paper on Territorial Cohesion: turning territorial diversity into strength“. Communication from th e Commission to the Council, the European Parliament, the Committee of the Regions and the European Economic and Social Committee, Brussels. Available at http://ec.europa.eu/regional_policy/archive/consultation/terco/ paper_terco_en.pdf (9. 9. 2019.)

Dragičević, M., Letunić, P. (2008) „Strengths and Constraints of Regional Development in Croatia“. An Enterprise Odyssey: Tourism - Governance and Entrepreneurship, Zagreb: Ekonomski fakultet Zagreb, pp. 114-129.

Hansen, P., Knowles, S. (1998) “Human capital and returns to scale”. Journal of Economic Studies, Vol. 25, No.2, pp. 118123. http://dx.doi.org/10.1108/01443589810202120

Ivan, A. L., lov, C. A. (2010) „Croatia: Administrative Reform and Regional Development in the Context of EU Accension“. Transylvanian Review of Administrative Sciences, Vol. 6, No. 31, pp. 93-113.

Judson, R. (1996) “Do Low Human Capital Coefficients Make Sense?: A Puzzle and Some Answers”. Division of Research and Statistics, Division of Monetary Affairs, Federal Reserve Board. http://dx.doi.org/10.17016/FEDS.1996.13

Koerner, K., Bletzinger, T., Lanzeni, M. L., AG, D. B., Hoffmann, R. and Speyer, B. (2013) „Croatia facing challenges on the EU's doorstep". Available at http://www.dbresearch.com/PROD/RPS_EN-PROD/PROD00000000000457230/ Croatia_facing_challenges_on_the_EU\%27s_doorstep.PDF (8. 9. 2019.)

Lejour, Arjan M., Mervar, A., Verweij, G. (2008) „The Economic Effects of Croatia's Accession to the EU“. E c o n o $\mathrm{m}$ i c s Discussion Paper. No. 2008-6. http://dx.doi.org/10.2139/ssrn.1726704

Mankiw, N. G., Romer, D., Weil, D. N. (1992) „A contribution to the empirics of economic growth”. The Q u a r t e r I y Journal of Economics, Vol. 107, No. 2, pp.407-437. http://dx.doi.org/10.2307/2118477

Marijanović, G., Čućić, D., Žalac, G. (2010) „Role Of Development Agencies In The Regional Development Of The Republic Of Croatia“. Interdisciplinary Management Research, Josip Juraj Strossmayer University of Osijek, Faculty of Economics, Croatia, Vol. 6, pp. 990-1000.

Otani, I., Villanueva, D. (1990) “Long-term growth in developing countries and its determinants: An Empirical Analysis". World Development. Vol. 18, No. 6, pp.769-783.

Poorfaraj, A., Samimi, A. J., Keshavarz, H. (2011) "Knowledge and economic growth: Evidence from some developing countries". Journal of Education and Vocational Research, Vol. 1, No.1, pp.21-25. http://dx.doi.org/10.22610/jevr. v1i1.4

Ravlić, S. (2019) "Implemented projects in the cross-border area and their impact on the development of human resources and the increase of revenues". Unpublished doctoral dissertation. University of J. J. Strossmayer, Postgraduate doctoral study "Management", Croatia, Osijek.

Strategic Framework for Development of Republic of Croatia 2006-2013. Available at https://razvoj.gov.hr/ UserDocsImages//arhiva/Publikacije//Strateski_okvir_za_razvoj_2006_2013.pdf(7.9. 2019.) 
S. Ravlić, J. Glavaš, M. Šimunić: The Impact of the IPA Cross-Border Co-operation Hungary - Croatia... Zbornik Veleučilišta u Rijeci, Vol. 8 (2020), No. 1, pp. $135-149$

Swinburn, G. (2006) "Argumentation and Reference Paper on Local Economic Development". Available at https:// www.eda.admin.ch/dam/deza/en/documents/themen/privatsektorentwicklung/162773-led-argumentationpaper_EN.pdf (8. 10. 2019.)

Tišma, S., Samardžija, V., Jurlin, K., (2012) “Hrvatska i Europska unija. Prednosti i izazovi članstva”. Institut za međunarodne odnose - IMO, Zagreb. Available at http://www.irmo.hr/wp-content/uploads/2013/11/hrvatska_i_eu_ prednosti_izazovi_.pdf (3. 10.2019.)

UNDP (1999) Human Development Report, Zagreb, Croatia. Available at http://hdr.undp.org/en/content/nationalhuman-development-report-croatia-1999 (3. 10. 2019.) 


\title{
UTJECAJ PROGRAMA IPA PREKOGRANIČNE SURADNJE MAĐARSKA - HRVATSKA 2007. - 2013. - INFRASTRUKTURA, TURIZAM I LJUDSKI KAPITAL
}

\author{
Sanela Ravlić \\ Dr. sc., viši stručni savjetnik za provedbu projekata, Hrvatski zavod za zapošljavanje, Regionalni ured Osijek, \\ Kneza Trpimira 2, 31000 Osijek, Hrvatska; e-mail: sanelaaaaa@gmail.com
}

Jerko Glavaš

Dr. sc., izvanredni profesor, Sveučilište J. J. Strossmayera u Osijeku, Ekonomski fakultet u Osijeku, Trg Ljudevita Gaja 7, 31000 Osijek, Hrvatska; e-mail: jerko.glavas@efos.hr

\section{Mislav Šimunić}

Dr. sc., redoviti profesor, Sveučilište u Rijeci, Fakultet za menadžment u turizmu i ugostiteljstvu, Primorska 42, 51410 Opatija, Hrvatska; e-mail: mislavs@fthm.hr

\begin{abstract}
SAŽETAK
Glavna surha ovog rada jest kvantificiranje i jasno razlikovanje postignuća uloženih IPA sredstava na području prekogranične suradnje Mađarske i Hrvatske 2007. - 2013. Cilj rada je pružiti uvid u stvarni utjecaj dodijeljenih financijskih sredstava u mjeri koja dosad nije ispitivana na razini institucija (vodeći korisnik i projektni partneri) i članova ciljne skupine. Glavno istraživačko pitanje jest kakav utjecaj su imali implementirani projekti u IPA CBC HU - CRO u pogledu različitih institucija, vrsta aktivnosti, korisnika u lokalnim zajednicama i regionalnog razvoja? Istraživanje je provedeno u travnju/svibnju 2018. godine. Upitnik se sastojao od 41 varijable. Intervju je bio korektivna metoda. Analiza podataka provedena je pomoću SPSS v23. Ukupno su sudjelovala 102 ispitanika, predstavnika 358 institucija koje su provodile projekte u prekograničnom području. Podaci su prvo analizirani korištenjem deskriptivne statistike, zatim uspoređeni pomoću t-testa i provedenog ANOVA Chi-kvadrat kako bi se utvrdila vjerojatnost korelacije između varijabli. Rad prikazuje rezultate na osobnoj, organizacijskoj i regionalnoj razini. Potvrdena je razlika ljudskog kapitala u razlicitim institucijama koje provode projekte i visoka ovisnosti EU fondova u cijeloj regiji. Krajnji korisnici su svjesniji utjecaja koji aktivnosti cjeloživotnog učenja mogu imati na njihovu konkurentnost na tržištu rada. Ulaganje u održivo okruženje, turizam, razvoj gospodarske suradnje, infrastrukturu i zajedničke ljudske kapacitete imat će značajan utjecaj na regiju.
\end{abstract}

Ključne riječi: Ljudski kapital, Europska unija, regionalni razvoj, prekogranična suradnja 